\title{
7. Örgütsel Davranış Kongresi Bildiri Kitabında Yer Alan Liderlik Ve Yöneticilik Konusundaki Çalışmalara İlişsin İçerik Analizi ${ }^{1}$
}

\section{Gülfer BÜYÜKTAȘ GAYIR}

Dr., Diyarbakır İl Sağlık Müdürlüğü,

Kamu Hastaneleri Hizmetleri Başkanlığ

gulxemdan@hotmail.com

Orcid ID: https://orcid.org/0000-0001-5064-0549

\author{
Zübeyir ÖZÇELİK \\ Dr., Türkiye İstatistik Kurumu Başkanlığ \\ zubeyir_ozcelik@hotmail.com \\ Orcid ID: https://orcid.org/0000-0001-7027-7396
}

\begin{abstract}
Öz
Örgütsel davranış alanının; giderek büyümesi, konularının farklı disiplinlerden beslenerek çeşitlenmesi, benzer konularda çok fazla araştırma ile derinleşmesi, örgütsel davranış kongrelerinin önemini ve akademik katkısını artırmışıı. Sonuncusu 1-2 Kasım 2019 tarihinde Burdur Mehmet Akif Ersoy Üniversitesi Bucak İşletme Fakültesi tarafından düzenlenen 7. Örgütsel Davranış Kongresinde 108 bildiri kabul edilmiştir. 108 bildiri arasında yer Alan "Liderlik ve Yöneticilik" konusundaki çalışmalar bu araştırmamızda içerik analiziyle incelenmiştir.

Bildiri kitabında yer alan "Liderlik ve Yöneticilik" konusundaki çalışmalar toplam çalışmaların \% 16'sını oluşturmaktadır. Bu çalışmaların çoğunluğunun birden fazla yazarlı olduğu ve ağırlıklı olarak nicel yöntemlerin kullanıldığ 1 saptanmıştır. Veri toplama aracı olarak çoğunlukla anket kullanılmış ve veriler genellikle betimleyici analizlerle değerlendirilmiştir.
\end{abstract}

Anahtar Kelimeler: Örgütsel Davranış, Örgütsel Davranış Kongresi, Liderlik, Yönetim.

\footnotetext{
${ }^{1}$ Makale Geliş/Kabul Tarihi: 28.05.2020 / 03.02.2021

Künye Bilgisi: Büyüktaş Gayır, G. ve Özçelik, Z. (2021). 7. Örgütsel davranış kongresi bildiri kitabında yer alan liderlik ve yöneticilik konusundaki çalışmalara ilişkin içerik analizi. Kahramanmaraş Sütçü İmam Üniversitesi Sosyal Bilimler Dergisi, 18(1), 558576. DOI: $10.33437 / k s u s b d .743207$
} 


\title{
G.Büyüktas Gavır-Z.Özçelik 7. Örgütsel Davranıs Kongresi Bildiri...
}

\section{Content Analysis Related to the Studies on Leadership and Management in the 7th Organizational Behavior Congress Proceedings Book}

\begin{abstract}
The field of organizational behavior has grown day by day. Its subjects have diversified from different disciplines, and its deepening with much research on similar topics has increased the importance and academic contribution of organizational behavior congresses. The last congresses were held on 1-2 November 2019 at Burdur Mehmet Akif Ersoy University School of Business. There were accepted 108 papers in this congress. The work on "leadership and management" among the 108 papers was evaluated by content analysis in this research.

The studies on "leadership and management" included in the paper which constitutes $16 \%$ of the total studies. It was determined that the majority of these studies had more than one author and mainly used quantitative methods. A survey method was often used as a data collection tool, and the data was often evaluated with descriptive analyses.
\end{abstract}

Keywords: Organizational Behavior, Congress of Organizational Behavior Leadership, Management.

\section{GíRiş}

Örgütsel davranış alanı, insanların bir organizasyon içindeki yerleşik düşünceleri, duyguları, hisleri ve davranışları ile ilgilenen bir disiplindir. Bireysel davranışı anlamak bir hayli cesur bir düşüncedir fakat bir organizasyon içinde grup davranışını anlamak çok daha önemli bir yönetsel görevdir. Hem bireylerle hem de insan gruplarıyla ilgili olan örgütsel davranış alanı son derece ilginçtir. Bu bağlamda Vijichristiana'nın (2017: 2) yaptığı tanıma göre örgütsel davranış; "bir organizasyonun yapı, teknoloji ve sosyal sistem gibi unsurlarının insan davranışlarıyla ilişkilendirmeye çalışan bir disiplindir".

Disiplinler arası bilgiyi içeren, bilimsel yöntemler kullanan örgütsel davranış, öncelikle bireylerin kariyer başarısında potansiyel artışına yardımcı olan ve böylece örgütsel performansı geliştiren bir uğraşı alanıdır (Schermerhorn vd., 2012: 4). Antropoloji, ekonomi, politika, felsefe ve sosyoloji gibi bir sosyal bilim olan örgütsel davranış diğer disiplinlere nazaran daha yenidir. Ayrıca örgütsel davranış uygulamalı bir bilim dalı olarak işin felsefesinden ziyade uygulamadaki sorunlarla ilgilidir (Miner, 2002: 4). Bu anlamda örgütsel davranış çalışmaları, 
1950'li yılların sonunda, 1960'lı yılların başında ayrı bir uzmanlık alanı olarak insan ve yönetim sorunlarına dair farklı bakış açılarını bütünleştirmek ve geliştirmek için örgüt içindeki davranış dinamiklerinin anlaşılması amacıyla ortaya çıkmıştır. 1980'li yıllardan sonra örgütsel davranışın, örgütlerin verimliliğinde önemli bir yer tuttuğunun belirginleşmesiyle birlikte yapılan araştırmaların arttığı gözlenmiştir (Akyol ve Akçay, 2015: 153).

Örgütsel Davranış disiplini, uygulamalı bir bilim dalı olması münasebetiyle gerek ülkemizde gerekse uluslararası alanda son dönemlerde yaygın bir şeklide araştırmacılar tarafından odak noktası haline gelmiştir. Bu gelişmeye bağlı olarak ülkemizde düzenlenen Ulusal İşletmecilik ve Ulusal Yönetim ve Organizasyon kongrelerinde örgütsel davranış alanında yapılan çalışmaların sayısı önemli bir rakama ulaşmıştır. Nitekim 1996 ile 2008 yılları arasında Ulusal Yönetim ve Organizasyon kongrelerinde sunulan bildiriler toplamının yaklaşık üçte biri Örgütsel Davranış alanında yer aldığı, dolayısıyla örgüt bilimleri içinde bir alt alan olarak Örgütsel Davranış çalışmalarına araştırmacıların göreceli olarak daha fazla ilgi gösterdiği belirlenmiştir (Erdem, 2009: 68).

Örgütsel davranış alanında kongre düzenleme fikrinin ortaya atılmasını takip eden süreçte ilk örgütsel davranış kongresi Sakarya Üniversitesi İşletme Fakültesi tarafından 15-16 Kasım 2013 tarihinde Sakarya'da düzenlenmiştir. Son örgütsel davranış kongresi olan 7. Kongre ise Burdur Mehmet Akif Ersoy Üniversitesi Bucak İşletme Fakültesi tarafından 1-2 Kasım 2019 tarihinde düzenlenmiştir. "7. Örgütsel Davranış Kongresi Bildiri Kitabında Yer Alan Liderlik ve Yöneticilik Konusundaki Çalışmaları İncelemek" amacıyla yapılan bu araştırma üç kısımdan oluşmaktadır. "Kuramsal Çerçeve" başlıklı birinci kısımda liderlik ve yöneticilik kavramları konusunda ilgili literatürde yer alan bilgiler irdelenmiştir. "Metodoloji" başlıklı ikinci kısımda ise; çalışmada kullanılan analiz yöntemi, araştırmanın amacı ve çalışma soruları, araştırma veri setinin (örnekleminin) belirlenmesi, araştırma kategorilerinin oluşturulması ile kodlama cetvelinin oluşturulması aşamaları yer almaktadır. Bulgular kısmı çalışmanın üçüncü kısmını oluşturmaktadır.

\section{KURAMSAL ÇERÇEVE}

\section{Lider}

Liderlik kavramını tanımlamadan önce kısaca lider kavramına bakmak gerekmektedir. En kısa tanımıyla lider, başarılı olmak için kendini parçalamak/yıpratmak durumunda kalmayan kişidir. Yani "işleri bizzat yapan değil yaptıran rolünü" üstlenen kişidir (Maxwell, 2012: 2). Lider-izleyici arasındaki ilişkiden hareketle yapılan bir tanıma göre de yönetici; izleyicilerin davranışlarını etkileyen sosyal bir etkileşim sürecidir (Desborough ve Ashikamasy, 2002: 615). 


\section{G.Büyüktas Gavır-Z.Özçelik 7. Örgütsel Davranıs Kongresi Bildiri...}

Daha geniş bir tanıma göre lider; belirli bir durum, zaman ve şartlar altında bağlı olduğu grubun üyelerini, örgüt amaçlarını gerçekleştirebilmek için gönüllü olarak çaba göstermeye teşvik eden, ortak amaçlara ulaşabilmeleri için onlara katkı sağlayan ve kendi tecrübelerini de aktarıp takipçilerinin liderlik tarzından memnun olmalarını sağlayan kişidir (Yekeler, 2015: 42).

Diğer bir ifadeyle de lider, bir örgütteki ya da kişiler arasındaki farklı sorunları çözebilme gücüne sahip olan, örgüt kültürünü oluşturan, yöneten ve bazen de değiştirebilen, insanları bir amaç doğrultusunda toplayan, yol gösteren, aydınlatan sahip olduğu iç motivasyon ve kişisel özellikleri nedeniyle insanlar üzerinde etki sahibi olan; kişilerin düşüncelerini önemli ölçüde değiştirebilen ve etkileyebilen kişidir (Cinnioğlu, 2018: 3).

\section{Liderlik}

Liderin yaptığı şeylerle ilgili bir süreç olan liderlik, yönetim ve davranış bilimleri arasında oldukça önemli bir kavram olan ve özellikle 21. yüzyılda dünyada başlayan değişim ve gelişimlere paralel olarak üzerinde çok fazla çalışılan konuların başında gelmektedir. 1980-1990 yılları arasında da liderlik mikro örgütsel davranış araştırmalarında sıklıkla ele alınan konulardan birisi olmuştur (Altıntaş ve Aytaç, 2018: 172). Çünkü örgütsel yaşamda oluşan gruplarda üyelerin diğerlerinin eylemlerini bir biçimde etkiledikleri süreçler boyunca liderlik rolü de biçimsel veya biçimsel olmayan bir şekilde gelişmektedir (Zenger, 2016: 5).

Liderlik tanımları, çeşitli kriterlere göre farklılık göstermektedir. Diğer yandan liderlik tanımları dünyada yaşanan değişim ve gelişimlere paralel olarak zamana göre de farklılık göstermektedir. Örneğin 1950'li yıllardaki tanımına göre liderlik bir grup aracılığıyla hedefe ulaşma aktivitesidir. 1960'larda ise liderlik bireylerin birbirini etkilemesi olarak görülmüştür. 1970'li yıllarda da liderlik bireyler arasındaki karşılıklı ilişkiler açısından tanımlanmıştır. 1980'lerde de liderlik ile ilgili 110 farklı tanım saptanmıştır. Bu dönemde özellikle örgütsel davranışçılar arasında liderlik tanımlarına geleneksel yaklaşım ağırlıktadır (Rost, 1993: 56).

Liderlik kavramı ile ilgili literatür incelendiğinde çalışmaların pek çoğunun çerçevesini; liderlerin taşıması gereken özellikler, ne yapmaları ve nasıl davranmaları gerektiği, karar verme aşamaları, örgütsel süreçlerdeki etkinlikleri, liderlik teorileri konularının oluşturduğu görülmektedir (Hotamışlı ve Efe, 2015: 103). Bu kapsamdaki tanımlardan birisine göre liderlik; grubun diğer üyelerinden karizma, zekâ, yetenek gibi özellikler açısından sahip olunan üstünlüktür. Liderliği daha iyi anlayabilmek için onunla ilgili anahtar kavramlara odaklanmak gerekmektedir. Liderliğin anahtar kavramları karizma, güç, otorite, izleyici ile bağ ve izleyici ile uyumdur (Stanfield, 2009: 26). 


\section{Liderlik Konusunda Türkiye'deki Bilimsel Çalışmaları İrdeleyen Araştırmalar}

Lider ve liderlik konusunda Türkiye'deki bilimsel çalışmaları irdeleyen müstakil araştırmalar olduğu gibi "örgütsel davranış ve yönetim-organizasyon konusundaki araştırmalar" içerisinde lider ve liderlik konusunda çalışmaların irdelendiği görülmektedir. Doğrudan ya da dolaylı olarak "lider ve liderlik konusunda Türkiye'deki bilimsel çalışmaları irdeleyen" araştırmalardan tespit edilebilen birkaç çalışma araştırmamızda örnek olarak ele alınmıştır.

Bu kapsamda, lider ve liderlik konusunda Türkiye'deki bilimsel çalışmaları irdeleyen araştırmalardan birisi Özkan (2016) tarafından yapılmıştır. Özkan (2016: 615), "Liderlik Hangi Sıfatları, Nasıl Alıyor? Liderlik Konulu Makalelerin İncelenmesi" başlıklı makalesinde; "Türkiye'deki bilimsel dergilerde yayınlanan liderlik konulu makalelerin; çalışma alanlarının, kullanılan yöntem ve örneklem büyüklüğü gibi metodolojik özelliklerinin, çalışmaların yapıldı̆̆ kademelerinin, çalışmaya konu olan öznelerin ve bu çalışmalarda liderliğin hangi sıfatları aldığının belirlenmesi” üzerinde durmuştur.

Lider ve liderlik konulu çalışmaları da içeren daha geniş kapsamlı bir araştırma Erdem (2009) tarafından yapılan "Örgütsel Davranış Araştırmalarında Niş Alanlar Nasıl Belirleniyor? Ulusal Yönetim ve Organizasyon Kongresi Yazını Üzerine Kısa Bir Değerlendirme” başlıklı araştırmadır. Erdem (2009: 67); "akademik gelişim sürecinin tutarlı ve bağlantılı aşamalardan geçtiğini, bunun için de araştırma nişlerinin iyi belirlenmesine ve bu nişlerde derinleşmeye ihtiyaç olduğunu ancak yerel boyutta bir derinleşme sorunu yaşadığını vurgulamak" amacıyla bu araştırmayı yaptığını ifade etmektedir.

Lider ve liderlik konulu çalışmaları da içeren daha geniş kapsamlı bir başka araştırma Kızıldağ ve Özkara (2016) tarafından yapılan "Türkiye'de Örgütsel Davranış Araştırmalarındaki Yönelimler: Ulusal Yönetim ve Organizasyon Kongresi Örneği” başlıklı araştırmadır. Bu araştırmada, Kızıldağ ve Özkara (2016: 614) "sanayi devriminden günümüze araştırma alanı genişleyen örgütsel davranış alanındaki çalışmaların Türkiye'deki yönelimi” incelenmiştir.

Türkiye'deki lider ve liderlik konulu çalışmaları da içeren daha kapsamlı çalışmaların "değişkenlerinin, konularının ve içeriklerinin dünyadaki eğilimlere paralel olarak ilerleyip ilerlemediğini tespit etmek" amaciyla; Aykan vd., (2018) tarafından bir araştırma yapılmıştır. Bu araştırmada yapılan analizler sonucunda, içerik analizi boyutunda her iki literatürde de benzerlikler olduğu ortaya konmuştur.

Lider ve liderlik konulu çalışmaları da içeren bir araştırma da Turgut ve Beğenirbaş (2016) tarafından yapılan “Türkiye'deki Örgütsel Davranış Yazınına 


\section{G.Büyüktas Gavır-Z.Özçelik 7. Örgütsel Davranıs Kongresi Bildiri...}

Bakış: Örgütsel Davranış Kongrelerinin Yazar ve İçerik Yönünden A $\breve{g}$ Analizi ile İncelenmesi” başlıklı araştırmadır. Bu araştırmada "1. ve 2. örgütsel davranış kongrelerinin bildiriler kitabında yer alan bildiriler içerik ve yazar yönünden ă analizi ile incelenmiştir”.

Benzer şekilde lider ve liderlik konulu çalışmaları da içeren daha geniş kapsamlı bir araştırma da Kaplan ve Kaplan (2019) tarafından yapılan "Amme İdaresi Dergisinde Örgütsel Davranış Alanının İzini Sürmek: Yazın Ölçme ve Değerlendirme Çalışması (2008-2018)” başlıklı araştırmadır. Bu araştırma “Türkiye'nin en köklü dergilerinden biri olan Amme İdaresi Dergisi'nde örgütsel davranış alanının mevcut durumunu belirlemeye yöneliktir”.

Lider ve liderlik konulu çalışmaları da içeren daha kapsamlı bir araştırma da Akyol ve Akçay (2015) tarafindan yapılan "Türkiye'deki Örgütsel Davranış Çalışmalarının Analizi” başlıklı araştırmadır. Bu araştırmada "Türkiye'deki Sosyal Bilimler ve Eğitim Bilimleri Enstitülerinde örgütsel davranış alanında yapılmış olan ve Yüksek Öğretim Kurumu Elektronik Tez Arşivinde yer alan lisansüstü tezler belirlenmiş kriterler çerçevesinde analiz edilmiştir”.

\section{Liderlik-Yöneticilik Farkı}

"Lider ve Liderlik" ile "yönetici ve yöneticilik" terimleri sık s1k birbirinin yerine kullanılmaktadır. Diğer yandan ise her iki terim birbirine tamamen zıt olarak da görülmektedir. Çünkü liderlik ile yöneticilik arasında belirgin benzerlikler bulunabilmekle birlikte aralarında birtakım önemli farklılıklar da bulunmaktadır (Herdman, 2012: 4). Bu anlamda yönetici başkalarına iş gördürme, başkaları aracılı̆̆ ile iş yapma/başarma ve amaçlara ulaşma mesleğini icra eden kişidir (Mücevher, 2019: 21). Diğer bir ifadeyle yönetici, kârı ve riski başkalarına ait olmak üzere ücret karşıllı̆ı başkaları ile iş birliği yaparak ürün ve hizmet üretmek için üretim faktörlerini bir araya getiren ve işletmeyi çalıştırmakla sorumlu olan kişidir (Mücevher, 2019: 22).

Yönetici ile ilgili tanımların çok fazla sayıda ve çeşitlilikte olmasına karşın hepsinde ortak bir nokta bulunmaktadır. $\mathrm{O}$ da yöneticinin gerçekleştirdiği faaliyetin, temelde "yönetimsel iş, Yönetin/yöneticilik)" olduğudur. Bu nedenle yöneticiyi tanımlarken, öncelikle, yönetimsel işin ne olduğunun açıklı̆̆a kavuşturulması gerekmektedir (Torrington ve Hall, 1987: 392). Bu bağlamda yönetimsel iş; yöneticinin oynadığı planlama, örgütleme, harekete geçirme ve kontrol rollerinden oluşmaktadır (Dobrin, 2012: 11).

Daha geniş bir ifadeyle planlama, örgütleme, yöneltme, koordinasyon ve denetim gibi yönetsel süreçlerin kullanılarak, bir örgütün amaç ve hedeflerine ulaşabilmesi için çaba sarf edilmesi ve bu uğurda çalışanların kolektif bir şekilde hareket etmesinin sağlanması sürecine de yöneticilik denir (Mücevher, 2019: 21). 
Liderlikle yöneticilik arasındaki ortak özellik; her ikisinin de bulunduğu örgütlerdeki kişi ya da grupları belirli amaçlara ulaşmak için yönetme ve yönlendirme çabası içerisinde olmalarıdır. Liderlik ve yöneticilik aynı şeyler olmamasına rağmen örtüştükleri de açıktır. Bundan dolayı günümüzde yöneticinin başarılı olabilmesi için liderlik niteliklerine de sahip olması gerektiği kabul edilmektedir. Nitekim bugün bu iki kavramın birleşiminden oluşan lider yöneticiler kavramı kullanılmaktadır (Sarığlu, 2014: 131).

\section{METODOLOJí}

\section{Çalışmada Kullanılan Analiz Yöntemi}

"7. Örgütsel Davranış Kongresi Bildiri Kitabında Yer Alan Liderlik ve Yöneticilik Konusundaki Çalışmaları İncelemek" amacıyla nitel olarak tasarımlanan bu çalışmada içerik analizi tekniği kullanılmıştır. İçerik analizi sosyal alanlarda ve ilişkili disiplinlerde araştırmacılarca oldukça yaygın bir şekilde kullanılmaktadır. Kalitatif bir yöntem olarak görülen içerik analizinin hata içermediği ancak sınırlı bir mana ifade ettiği düşünülmektedir. İçerik analizinde kullanılan temel mantık kelime hesabına dayanmaktadır (Drisko ve Maschi, 2016: 1). Bu yöntemde bir dokümanda tekrarlanan ifadeler belirli standartlar dahilinde kodlanarak daha küçük içerik kategorilerine dönüştürülür ve sistematik bir şekilde özetlenir (Akaydın ve Çeçen, 2015: 186). Yaklaşık olarak 60 yıllık geçmişi olan içerik analizinin ilk tanımı 1961 yılında "Webster's Dictionary of the English Language'de” görülmektedir. Buradaki tanıma göre içerik analizi; "herhangi bir materyalin (film veya kitap gibi) içerisinde gizlenmiş olan mesaj içeriklerinin sınıflandırılması, çizelgeye dökülmesi ve anahtar sembollerinin değerlendirilmesi suretiyle anlamlarını kesinleştirme analizidir" (Krippendorff, 2004).

İçerik analizinin tanımı, zaman içinde yeni tekniklerin ve uygulamaların da ortaya konulmasıyla değişim göstermiştir. Bu tanımlardan birine göre içerik analizi veriden onun içeriğine ilişkin tekrarlanabilir ve geçerli sonuçlar çıarmak üzere kullanılan bir araştırma tekniğidir (Koçak ve Arun, 2006: 22). Diğer bir ifadeyle herhangi bir dokümanda veya materyalde kullanılan bir anahtar kavramın tekrar sayısından bağlamına uygun çıkarımda bulunma tekniğidir (Drisko ve Maschi, 2016: 2). İçerik analizi, toplum bilimlerinin neredeyse her alanında kullanılır. İçerik analizi yönteminin metodolojik anlamda disiplinler arası kullanımının nedeni, bu yöntemin esnek yapısıdır. $\mathrm{Bu}$ esneklik, içerik analizi yönteminin en güçlü özelliğidir. Bu yüzden içerik analizi, bilimsel bir yöntem olarak sosyal bilimler alanında kendine önemli bir yer edinir (Çilingir, 2017: 2). Ayrıca, içerik analizinde vurgulanan iki önemli konu, yöntemin "sistematik" ve "tarafsız" olması gerektiğidir (Koçak ve Arun, 2006: 2).

Toplanan verileri açılayabilecek kavramlara ve ilişkilere ulaşmak amacıyla 


\section{G.Büyüktas Gavır-Z.Özçelik 7. Örgütsel Davranıs Kongresi Bildiri...}

kullanılan içerik analizi, dokümanlardan elde edilen nitel araştırma verilerinin işlenmesi, verilerin kodlanması, temaların bulunması, kodların ve temaların düzenlenmesi, bulguların tanımlanması ve yorumlanması gibi aşamalardan oluşmaktadır (Sert vd., 2012: 353).

İçerik analizi çalışmalarında, akademik dokümanların (akademik dergi, bildiri kitabı, veri tabanı) farklı yöntemler kullanılarak tarandığı tespit edilmiştir. Bu yöntemlerden birincisi benzer temalı birden fazla dokümanın içeriğinde bulunan yayınların (makale, bildiri) karşılaştırmalı analizlerinin yapıldığ 1 çalışmalardır. Bir diğer yöntem bir veya daha fazla dokümanın içeriğinde bulunan yayınların belirli konular açısından analizlerinin yapıldığ yöntemlerinden üçüncüsü, belirli bir akademik dokümanın içeriğinde bulunan yayınlarda yapılan katkıların kaynağına göre analizlerinin yapıldığ 1 çalışmalardır. Doküman tarama yöntemlerinden dördüncüsü, akademik bir dokümanın içeriğinde bulunan yayınların tesadüfi örneklem ile seçilerek analizlerinin yapıldığı çalışmalardır (Kaya vd., 2013: 27).

Bu çalışmada "bir dokümanın içeriğinde bulunan bildirilerin belirli kategoriler açısından analizlerinin yapıldı̆̆ı" yöntem tercih edilmiştir.

\section{Araştırmanın Amacı ve Çalışma Soruları}

Temel düzeyde konuya ilişkin literatür taraması sonucunda araştırmanın amacı; "7. Örgütsel Davranış Kongresindeki Bildiri Kitabında Yer Alan Liderlik ve Yöneticilik" konusundaki çalışmaları incelemek" şeklinde belirlenmiştir. Araştırmanın amacı doğrultusunda araştırma soruları da aşağıdaki şekilde oluşturulmuştur:

Çalışmaların "tek ve çok yazarlı" kriter açısından sayıları ve oranları hangi düzeylerdedir?

Araştırmada kullanılan "nitel ve nicel yöntemler" açısından çalışma sayıları ve oranları hangi düzeylerdedir?

Araştırmada kullanılan "örneklem türü” açısından çalışma sayıları ve oranları hangi düzeylerdedir?

Araştırmada kullanılan "veri toplama araçları" açısından çalışma sayıları ve oranları hangi düzeylerdedir?

Araştırmada kullanılan "veri analiz tekniği/yöntemi" açısından çalışma sayıları ve oranları hangi düzeylerdedir? 
Çalışmalar içinde "liderlik veya yöneticilik" kavramlarından her birinin ayrı sayıları ve "liderlik veya yöneticilik" çalışmaları içindeki oranları hangi düzeylerdedir?

"Liderlik veya yöneticilik" konulu bildirilerin toplam bildiriler içindeki oranları hangi düzeylerdedir?

\section{Araştırma Veri Setinin (Örnekleminin) Belirlenmesi}

Araştırmanın veri setine (örnekleme) ilişkin sınırlamada kullanılan temel yaklaşımlar aşağıda açıklandığı şekildedir:

$\checkmark$ Nerede: Veriler, Türkiye'ye ilişkindir

$\checkmark$ Ne Zaman: Veriler, 01-02 Kasım 2019 y1lına aittir.

$\checkmark$ Hangi Aracıyla: Veri seti, "7. Örgütsel Davranış Kongresi Bildiri Kitabından" üretilmiştir.

$\checkmark$ Hangi Konuda: Veriler, 7. Örgütsel Davranış Kongresi Bildiri Kitabında Yer Alan Liderlik ve Yöneticilik Konusundaki Çalışmalara ilişkindir.

\section{Araştırma Kategorilerinin Oluşturulması}

Araştırmanın amaca uygun ve anlamlı bir şekilde aşağıdaki yedi kategori belirlenmiştir.

$\checkmark$ "Tek ve çok yazarlı" olarak hazırlanan bildiri sayıları ve oranları

Araştırmada kullanılan "nitel ve nicel yöntemler" açısından çalışma sayıları ve oranları

$\checkmark$ Araştırmada kullanılan "örneklem türü” açısından çalışma sayıları ve oranlar1

Araştırmada kullanılan "veri toplama araçları" açısından çalışma sayıları ve oranlar1

Araştırmada kullanılan "veri analiz tekniği/yöntemi” açısından çalışma sayıları ve oranları

Çalışmalar içinde "liderlik veya yöneticilik" kavramlarından her birinin ayrı sayıları ve "liderlik veya yöneticilik" çalışmaları içindeki oranları

"Liderlik veya yöneticilik" konulu bildirilerin toplam bildiriler içindeki oranlar1 


\section{G.Büyüktas Gavır-Z.Özçelik 7. Örgütsel Davranıs Kongresi Bildiri...}

Araştırma kapsamında oluşturulan kategoriler homojendir. Çünkü kategoriler birbirlerinden bağımsızdır ve bir kategoriye dahil edilen bir birim diğer birimleri etkilememektedir. Kategoriler aynı zamanda bütünsellik/eksiksizlik arz etmektedir. Diğer yandan kategoriler ayırt edicidirler. Nitekim bir çözümleme birimi yalnız ve yalnız o kategoriye yerleştirilmiştir.

\section{Kodlama Cetvelinin Oluşturulması}

Araştırmanın veri seti tek bir birimden gelen bilgileri içermektedir. Bu yüzden farklı birimlerden gelen verilerden veya kodlayıc1lardan kaynaklı herhangi bir tutarsızlık olasılığı ortadan kalkmıştır. Birden fazla kodlayıcının bulunmuyor olması nedeniyle de "bireysel güvenirlik" sorunu da bulunmamaktadır. Diğer yandan kayıt birimlerinin sınırlarının standart olarak belirlenmiş olması münasebetiyle "kategori güvenirliği de" sağlanmıştır.

\section{Bulgular}

Çalışmaların "tek ve çok yazarlı” kriter açısından dağılımı:"7. Örgütsel Davranış Kongresindeki Bildiri Kitabında Yer Alan Liderlik ve Yöneticilik" konusundaki çalışmaların "tek ve çok yazarlı" kriter açısından dağılımı Tablo 1'de gösterildiği şekildedir.

Tablo 1. Yazar Sayısına Göre Dağılım

\begin{tabular}{ccc}
\hline Yazar Sayısı & Sayı & Oran \\
\hline Tek Yazarlı & 7 & 29.1 \\
\hline Çok yazarlı & 17 & 70.9 \\
\hline Toplam & 24 & 1.00 \\
\hline
\end{tabular}

Tablo 1'de Kongre Bildiri Kitabındaki çalışmaların büyük kısmının $(\% 70,9)$ çok yazarlı olduğu görülmektedir. Çok yazarlı çalışmalardan 10 çalışma iki yazarlı; üç çalışma üç yazarlı, yine üç çalışma dört yazarlı ve bir çalışma da beş yazarlıdır. Çok yazarlı çalışmalardan 10 araştırmanın yazarları farklı üniversitelerden; 7 araştırmanın yazarlanı ise aynı üniversitedendir. Yine çok yazarlı çalışmalardan 14 araştırmanın yazarları akademisyenlerden oluşurken; 3 araştırmayı akademisyen olmayan araştırmacılarla akademisyenlerin birlikte hazırladıkları görülmektedir.

Çok yazarlılık kolektif çalışma bilincini yansıtması açısından bir avantaj oluşturmaktadır. Çünkü kolektif çalışma "birleştirilmiş zekâyı" yansıtmaktadır. Ortak çalışma grubundaki kişilerden her biri düşüncelerini bağımsızca açıklayabilmekte ve daha sonra bu düşüncelerin en iyilerine birlikte karar verilmektedir. Çok yazarlılığın bir avantajı da "yarattı̆̆ı sinerjidir". Ortak çalışma 
aynı zamanda ve aynı sonuca ulaşmak isteyen araştırmacıların bu amaçla uyumlu ve ortak güç ortaya çıkartma gayretlerini yansıtmaktadır.

Ancak çok yazarlı çalışmalar "Haksız Yazarlık" şüphesine ve eleştirisine muhatap olma olasılığı içermektedir. Haksız yazarlık eleştirisi daha çok; "aktif katkısı olmayan kişileri yazarlar arasına dâhil etmek, yazar sıralamasını gerekçesiz ve uygun olamayan bir biçimde değiştirmek" şeklinde ortaya çıkabilmektedir. Haksız Yazarlık yönündeki şüphelerin araştırmacıların imkân ve kabiliyetlerini yansıtan tek yazarları çalışmaları ile ortadan kaldırılması mümkündür.

1994 y1lından günümüze kadarki Ulusal Yönetim ve Organizasyon kongrelerinde sunulan bildirilerin yazar sayısına bakıldığında, 2006 yılından itibaren iki yazarlı bildiri sayısında artış olduğu görülmektedir. 1994 ve 2000 yılındaki kongrelerde üç yazarlı, 2002 yılındaki kongrede ise dört yazarlı çalışmalar yer alsa da üç ve daha fazla yazarlı bildirilerin sayısı 2004 yılından itibaren artış göstermektedir. 2006 yılındaki kongrede ilk kez beş yazarlı, 2013 yılındaki kongre de ise ilk kez altı yazarlı bildiler yer almıştır. (Kızıldağ ve Özkara, 2016: 617).

Science Direct veri tabanında taranan ve başlığında "Liderlik" kavramı geçen 100 makaleden 80’i (\%80) çok yazarlıdır. "7. Örgütsel Davranış Kongresindeki Bildiri Kitaplarında Yer Alan Liderlik ve Yöneticilik" konusundaki çalışmaların "tek ve çok yazarlı" kriter açısından dağılımı ile Science Direct veri tabanında yer alan makalelerdeki dağılım yaklaşık olarak örtüşmektedir.

\section{Araştırmada Kullanılan "Nitel ve Nicel Yöntemler" Açısından Çalışmaların Dağılımı}

"7. Örgütsel Davranış Kongresindeki Bildiri Kitabında Yer Alan Liderlik ve Yöneticilik" konusundaki çalışmalarda kullanılan "Nitel ve Nicel Yöntemler" açısından dağılım Tablo 2'de gösterildiği şekildedir.

Tablo 2. Nitel ve Nicel Yöntemler Açısından Dağılım

\begin{tabular}{lcc}
\hline $\begin{array}{l}\text { Araştırma } \\
\text { Yöntemleri }\end{array}$ & Sayı & Oran \\
\hline Nicel & 16 & 66.66 \\
\hline Nitel & 7 & 29.16 \\
\hline Karma & 1 & 04.18 \\
\hline Toplam & 24 & 1.00 \\
\hline
\end{tabular}




\section{G.Büyüktas Gavır-Z.Özçelik 7. Örgütsel Davranıs Kongresi Bildiri...}

Tablo 2'de incelendiğinde çalışmaların çoğunluğunun $(\% 66,6)$ nicel çalışmalardan olduğu görülmektedir. Ancak nitel çalışmaların oranı da bir sosyal bilim alanı için küçümsenemeyecek düzeydedir. Bir çalışmada ise hem nitel hem nicel yöntem birlikte kullanılmıştır. Araştırma bulguları bu konuda yapılan çalışmalardaki bulgularla örtüşmektedir. Nitekim Aykan vd., (2018: 194) tarafından yapılan araştırmadan elde edilen deneyimler sonucunda Örgütsel Davranış Kongresi bildirilerinde ölçek geliştirme ve nicel araştırma yöntemlerinin daha fazla tercih edildiği sonucu çıkarılabileceği vurgulanmıştır. Benzer şekilde Türkiye'de örgütsel davranış araştırmalarındaki bildirilerde kullanılan yöntem açısından incelendiğinde, nicel yöntemlerin ağırlıklı olarak tercih edildiği görülmektedir (Kızıldağ ve Özkara, 2016: 621). Yapılan başka bir araştırmanın bulgularına göre 2008-2018 yılları arasında Amme İdaresi Dergisinde yayınlanan “Örgütsel Davranış Alanına” ilişkin çalışmaların \% 57'si nicel, \% 7'si nitel \% 36'sı da diğer tür (kavramsal, ölçek geliştirme) çalışmalardır (Kaplan ve Kaplan, 2019: 1236).

Nicel araştırma, sosyal ve fiziksel dünyanın aynı yöntemle incelenebileceğini, bu nedenle sosyal olguların doğa bilimlerinde kullanılan yöntemle incelenmesi gerektiğini savunan; sebep-sonuç ilişkilerini objektif, güvenilir ve geçerli bir biçimde irdelemeyi amaçlayan pozitivist yaklaşıma dayanır. Ancak günümüzde pozitivist yaklaşım, özellikle sosyal bilimler alanındaki araştırmalarda tek yaklaşım olmaktan çıkmış; teori oluşturma anlayışıyla sosyal olguları bağlı bulundukları çevre içerisinde araştırmayı ve anlamayı ön plana alan nitel araştırma, sosyal bilimler alanındaki araştırmalara yeni bir bakış açısı getirmiştir.

\section{Araştırmada Kullanılan “Örneklem Türü” Açısından Çalışmaların Dağılımı}

“7. Örgütsel Davranış Kongresindeki Bildiri Kitabında Yer Alan Liderlik ve Yöneticilik" konusundaki çalışmalarda kullanılan "Örneklem Türü” açısından dağılımı Tablo 3'te gösterildiği şekildedir.

Tablo 3. Örneklem Türü Açısından Dağılım

\begin{tabular}{lcc}
\hline $\begin{array}{c}\text { Araştırma } \\
\text { Yöntemleri }\end{array}$ & Sayı & Oran \\
\hline Veri Tabanları & 1 & 4.16 \\
\hline Sosyal A ̆ & 1 & 4.16 \\
\hline Doküman & 3 & 12.50 \\
\hline Yöneticiler & 3 & 12.50 \\
\hline Öğrenciler & 3 & 12.50 \\
\hline Akademisyenler & 1 & 4.16 \\
\hline İşörenler & 12 & 50.02 \\
\hline Toplam & 24 & 1.00 \\
\hline
\end{tabular}


Tablo 3 incelendiğinde bildiri kitabındaki araştırmaların genellikle işgörenler üzerinde yapıldığı (\%50) görülmektedir. Nitel çalışmalarda veri tabanlarının ve ilgili dokümanların tarandığı ya da araştırmacının sosyal ağında yer alan kişilerin örneklem olarak seçildiği anlaşılmaktadır.

\section{Araştırmada Kullanılan "Veri Toplama Aracı" Açısından Çalışmaların Dağılımı}

"7. Örgütsel Davranış Kongresindeki Bildiri Kitabında Yer Alan Liderlik ve Yöneticilik" konusundaki çalışmalarda yararlanılan "Veri Toplama Aracı" açısından dağılım Tablo 4'te gösterildiği şekildedir.

Tablo 4. Veri Toplama Aracı Açısından Dağılım

\begin{tabular}{lcc}
\hline $\begin{array}{l}\text { Veri Toplama } \\
\text { Araçları }\end{array}$ & Sayı & Oran \\
\hline Yazın Tarama & 1 & 4.00 \\
\hline Söylem Tarama & 1 & 4.00 \\
\hline Mülakat & 2 & 8.00 \\
\hline Doküman Analizi & 3 & 12.00 \\
\hline $\begin{array}{l}\text { Sosyal Medya } \\
\text { Hesabı Analizi }\end{array}$ & 1 & 4.00 \\
\hline Anket & 17 & 68.00 \\
\hline Toplam & 25 & 1.00 \\
\hline
\end{tabular}

Nicel araştırmaların tamamında veri toplama aracı olarak anket kullanılmıştır. Nitel araştırmaların birisinde de mülakat ile birlikte anketin de kullanıldığ 1 görülmektedir. Nitel araştırmalarda kullanılan araçların sıralamasında doküman analizi ve mülakat ilk iki sırayı alırken üçüncü sırada yazın tarama ve söylem tarama ile birlikte sosyal medya hesabı analizi yer almaktadır. Veri toplama araçları açısından dikkat çeken bir nokta sosyal deney ve gözlem yöntemlerinin tercih edilmemiş olmasıdır.

\section{Araştırmada Kullanılan "Veri Analiz Teknikleri" Açısından Çalışmaların Dağılımı}

“7. Örgütsel Davranış Kongresindeki Bildiri Kitabında Yer Alan Liderlik ve Yöneticilik" konusundaki çalışmalarda kullanılan veri analiz teknikleri açısından dağılım Tablo 5'de gösterildiği şekildedir.

Tablo 5. Veri Analiz Teknikleri Açısından Dağılım

\begin{tabular}{lcc}
\hline Değişkenler & Sayı & Oran \\
\hline Betimleyici istatistikler & 16 & 21.9 \\
\hline
\end{tabular}




\section{G.Büyüktas Gavır-Z.Özçelik 7. Örgütsel Davranıs Kongresi Bildiri...}

\begin{tabular}{lcc}
\hline Korelasyon Analizi & 11 & 15.2 \\
\hline Varyans Analizi & 3 & 4.1 \\
\hline Faktör Analizi & 8 & 10.9 \\
\hline Geçerlik- Güvenilirlik & 12 & 16.4 \\
\hline Regrasyon & 8 & 11.0 \\
\hline İçerik Analizi & 6 & 8.2 \\
\hline Diğer & 9 & 12.3 \\
\hline Toplam & 73 & 1.00 \\
\hline
\end{tabular}

Tablo 5'e dikkat edildiğinde Kongre Bildiri Kitabında en s1k kullanılan veri analiz tekniğinin betimleyici istatistikler olduğu; içerik analizinin kullanım oranının ise $\% 0,8$ olduğu görülmektedir (kullanılan veri analiz teknikleri içindeki ağırlığı \% 21,9). Üzerine çalışılacak verileri tanıma ve kurulacak modelleri yorumlama açısından betimleyici istatistikler önemli bir rol oynamaktadırlar. İkinci sırada en sık kullanılan veri analiz tekniğinin geçerlilik ve güvenilirlik testleri olduğu görülmektedir. Diğer analizler başlığı altında ise; gömülü kuram analizi, karşılaştırma analizi, ilişki analizi, farklılık analizi uyum iyiliği analizi ve sobel analizi yer almaktadır.

\section{Araştırmada Kullanılan "Liderlik-yöneticilik" Kavramları Açısından Çalışmaların Dağılımı}

“7. Örgütsel Davranış Kongresindeki Bildiri Kitabında Yer Alan Liderlik ve Yöneticilik” konusundaki çalışmalarda kullanılan liderlik-yöneticilik kavramlarının dağılımı Tablo 6'da gösterildiği şekildedir.

Tablo 6. "Liderlik-yöneticilik” Kavramları Açısından Dağılım

\begin{tabular}{ccc}
\hline Kavramlar & Sayı & Oran \\
\hline Liderlik & 17 & 70.9 \\
\hline Yöneticilik & 7 & 29.1 \\
\hline Toplam & 24 & 1.00 \\
\hline
\end{tabular}

Tablodaki verilere göre 7. Örgütsel Davranış Kongresindeki bildiri kitabında liderlik kavramı üzerine oturan çalışmaların "yöneticilik" başlıklı çalışmalara nazaran büyük çoğunluğa sahip olduğu anlaşılmaktadır. 1994 yılından günümüze kadarki Ulusal Yönetim ve Organizasyon kongrelerinde sunulan bildirilerde liderlik teması ilk kez 1994 yılındaki kongrede ele alınmış ve 2000 yılından sonraki her kongrede liderlik teması ile ilgili bildiri yer almıştır (Kızıldağ ve Özkara 2016: 619). Nitekim Ulusal Yönetim ve Organizasyon kongrelerinde sunulan Örgütsel Davranış araştırmalarının (247) \%13,7’si (34 bildiri) liderlik teması üzerine yoğunlaşmıştır (Erdem, 2009: 70). Benzer şekilde, Aykan vd., (2018: 193) yaptıkları bir araştırmada Türkiye'de 2013 yılından itibaren düzenli 
olarak gerçekleştirilen Örgütsel Davranış Kongresi kapsamında en sık çalışılan konulardan birinin liderlik olduğu tespit edilmiştir.

1990'lı yılların başında popülerlik kazanan çağdaş liderlik söylemi ve dönemin ikinci yarısında önem kazanan yeni tipolojiler yerel yazında 2000'li yıllarda araştırma temaları olarak ilgi çekmiştir. Dolaysıyla liderlik bazlı çalışmalarda dönüşümsel liderlik diğer liderlik türlerine göre daha fazla irdelenmiştir. Dolaysıyla bu sonuç konuya ilişsin yapılan çalışmaların sonuçlarıyla örtüşmektedir. Nitekim 1996-2008 yıllarında Ulusal Yönetim ve Organizasyon kongrelerinde sunulan bildirilerden 34 bildiri kapsamında dönüştürücü liderlik tipolojisine sıkça rastlanmaktadır. 1996-2000 yılları arasında yönetici profiline yönelik bazı araştırmalar daha sık iken, 2000 yılından sonra dönüştürücü-değişimci liderlik ve etik liderlik gibi temalara yönelik yerel araştırmaların sayısı artmıştır (Erdem, 2009: 71).

Liderlik ve yöneticilik kavramlarının ilişkilendirildiği değişkenler arasında ilk sırayı örgütsel bağlılık kavramı almaktadır. Bu bağlamda ikinci sırada "örgütsel özdeşleşme ile algılanan yönetici desteği" olguları gelmektedir. Daha sonra sırasıyla "lider/yönetici-üye etkileşimi, güven algısı, yönetici yetkinliği ve yönetici kibri” kavramları dikkat çekmektedir.

\section{SONUÇ VE TARTIŞMA}

Kuramsal bilgi stokundan çıkarılan sonuca göre örgütsel davranış bir organizasyonun yapı, teknoloji ve sosyal sistem gibi unsurlarını insan davranışlarıyla ilişkilendirmeye çalışan bir disiplindir. Dolaysıyla disiplinler arası bilgiyi içeren, bilimsel yöntemler kullanan örgütsel davranış öncelikle bireylerin kariyer başarısında potansiyel artışına yardımcı olmaya ve böylece örgütsel performansı geliştirmeye katkı sağlayan bir uğraşı alanıdır. Örgütsel Davranış disiplinin araştırmacılar tarafindan odak noktası haline gelmesiyle birlikte ülkemizde 15-16 Kasım 2013 tarihinde Sakarya Üniversitesi İşletme Fakültesi tarafindan ilk örgütsel davranış kongresi düzenlenmiştir. Son örgütsel davranış kongresi olan 7. Kongre ise Burdur Mehmet Akif Ersoy Üniversitesi Bucak İşletme Fakültesi tarafından 1-2 Kasım 2019 tarihinde düzenlenmiştir.

Son örgütsel davranış kongresi olan 7. Kongrenin Bildiri Kitabında "Yer Alan Liderlik ve Yöneticilik" konusundaki çalışmaların içerin analizine tabi tutulduğu bu araştırmada ulaşılan sonuçlara göre "7. Örgütsel Davranış Kongresindeki Bildiri Kitabında Yer Alan Liderlik ve Yöneticilik" konusundaki çalışmalar toplam çalışmaların \% 16'sını oluşturmaktadır. Konuya ilişkin olarak ulaşılan çalışmalarla bir mukayese yapıldığında bu çalışmalarda yer alan "liderlik ve yöneticilik" konulu araştırmaların 7. Örgütsel Davranış Kongresinde de çok düşük seviyedeki bir azalmaya rağmen oransal olarak önemini koruduğu görülmektedir. 


\section{G.Büyüktas Gavır-Z.Özçelik 7. Örgütsel Davranıs Kongresi Bildiri...}

Örnek bir karşılaştırma olması açısından bakıldığında "1. Örgütsel Davranış Kongresindeki Bildiri Kitabında Yer Alan Liderlik ve Yöneticilik" konusundaki çalışmalar toplam çalışmaların \% 20'sini oluştururken; "6. Örgütsel Davranış Kongresindeki Bildiri Kitabında Yer Alan Liderlik ve Yöneticilik" konusundaki çalışmalar toplam çalışmaların \% 22'sini oluşturmaktadır. Yine bir örnek karşılaştırma olması açısından bakıldığında "1. Örgütsel Davranış Kongresi Bildiri Kitabında yer alan bildirilerde" liderliğin derece merkezliliğinin en yüksek seviyede olduğu; "2. Örgütsel Davranış Kongresi Bildiri Kitabında yer alan bildirilerde" liderliğin derece merkezliliğinin üçüncü seviyede yer aldığg görülmektedir.

Mevcut akademik atama ve yükselme ölçütleri başta olmak üzere günceli izleyebilme ve bilgi stokuna katkı sağlama gibi nedenlerle araştırmacıların özellikle Amerikan merkezli yazında yer alan yeni ve güncel konulara yöneldikleri; Erdem'in (2009: 74) vurguladığı gibi akademik atama ve yükselme ölçütlerinin yerel yazını "popüler tema" kıskacına sıkıştırmış olabileceği ve bu nedenlerle de 7. Kongrede "liderlik ve yöneticilik" konulu çalışmalarda çok az da olsa bir düşüş gözlendiği söylenebilir.

Araştırmanın dikkate değer bulgularından birisi de "7. Örgütsel Davranış Kongresindeki Bildiri Kitabında Yer Alan Liderlik ve Yöneticilik" konusundaki çalışmalarda içerik analizinin kullanım sıklığına ilişkindir. "7. Örgütsel Davranış Kongresindeki Bildiri Kitabında Yer Alan Liderlik ve Yöneticilik" konusundaki çalışmalarda içerik analizinin kullanım sıklığı konuya ilişkin benzer çalışmalarındaki bulguların üzerindedir. Yapılan bir araștırmanın bulgularına göre 2008-2018 y1lları arasında Amme İdaresi Dergisinde yayınlanan "Örgütsel Davranış Alanına" ilişkin çalışmalarda içerik analizinin kullanıldığı çalışmaların oranı \% 3 iken (Kaplan ve Kaplan, 2019: 1238) "7. Örgütsel Davranış Kongresindeki Bildiri Kitabında Yer Alan Liderlik ve Yöneticilik" konusundaki çalışmalarda bu oran \% 8'dir. Bu sonuca göre en azından seçilen araştırma yöntemi bağlamında araştırmacıların "güvenilirliği test edilmiş" yöntemlerin kıskacına girmedikleri söylenebilir.

Araştırmanın bir diğer dikkate değer sonucu da "7. Örgütsel Davranış Kongresindeki Bildiri Kitabında Yer Alan Liderlik ve Yöneticilik" konusundaki çalışmalarda veri toplama aracı olarak "anket" yönteminin \%68 kullanım oranıyla ilk sırada yer almış olmasıdır. 7. Örgütsel Davranış Kongresindeki Bildiri Kitabında Yer Alan Liderlik ve Yöneticilik" konusundaki çalışmalarda "anket" yönteminin kullanım sıklığı konuya ilişkin benzer çalışmalarındaki bulgularla örtüşmektedir. Örneğin, Akyol ve Akçay (2015: 153) tarafindan yapılan bir araştırmanın bulgularına göre "Türkiye'deki Sosyal Bilimler ve Eğitim Bilimleri Enstitülerinde örgütsel davranış alanında yapılmış olan ve 
Yüksek Öğretim Kurumu (YÖK) Elektronik Tez Arşivinde yer alan lisansüstü tezlerde" anket yöntemi \% 91 kullanım oranıyla ilk sırada yer almaktadır.

Gelecekte "Örgütsel Davranış Kongrelerindeki Bildiri Kitaplarında Yer Alan Araştırmalar" konusunda yapılacak çalışmalarda, örgütsel davranışın diğer boyutlarından birisi veya birkaçı birden ya da tamamı incelenebilir. $\mathrm{Bu}$ araştırmalarda birden çok örgütsel davranış kongresinin bildiri kitabı veya yedi kongre kitabının tamamı analize tabi tutulabileceği gibi kongre kitapları arasında konu bazında karşılaştırmalı çalışmalar da yapılabilir. Bu karşılaştırmalar yerli ve yabanc1 yazın arasında da yapılabilir.

"Örgütsel Davranış Kongrelerindeki Bildiri Kitaplarında Yer Alan Araştırmalar" konusunda yapılacak çalışmalarda, ağ yapısı, söylem analizi ve bibliyometrik analiz gibi yöntemlerin kullanılması da önerilebilir.

\section{KAYNAKÇA}

Akaydın, Ş. ve Çeçen, M.A. (2015). A content analysis on articles related to reading skills, Education and Science, 40(178), 183-198.

Akyol, B. ve Akçay, R. C. (2015). Türkiye'deki örgütsel davranış çalışmalarının analizi, Eğitimde Kuram ve Uygulama, 11(1), 149-170.

Altıntaş, Füsun Çınar ve Aytaç, C. K. (2018). Örgütsel Davranış alanının gelişim çizgisini belirlemeye yönelik çok boyutlu ölçekleme çalışması (19652015), Balkan Sosyal Bilimler Dergisi, 7(13), 171-178.

Aykan, E., Koparan, E. ve Bellek, M. (2018). Örgütsel Davranış Çalışmaları Türkiye'de ve Dünyada Ne Şekilde Ilerlemektedir? Örgütsel Davranıs Kongresi ve Academy of Management Bildirilerinin Karşılaştırılması, [Sözlü Sunum]. 6. Örgütsel Davranış Kongresi Bildiriler Kitabı, 2-3 Kasım Isparta, 186-196.

Cinnioğlu, H. (2018). Etkileşimci liderlik, dönüşümcü liderlik, hizmetkâr liderlik, iş tatmini ve işten ayrlma niyeti ilişkisi: yiyecek içecek işletmelerinde bir araştırma [Doktora Tezi, Çanakkale Onsekiz Mart Üniversitesi Sosyal Bilimler Enstitüsü Turizm İşletmeciliği Anabilim Dalı], Çanakkale.

Çilingir, A. (2017). İletişim alanında içerik analizi yöntemi kullanılarak yapılan yüksek lisans ve doktora tezleri üzerine bir inceleme, Erciyes Illetişim Dergisi Akademia, 5(1), 148-160.

Desborough, M. T. ve Ashikamasy, M. (2002). Emotion and attribution of intentionalty in leader - member relationships, The Leadership Quarterly, 13(5) 615-634. 


\section{G.Büyüktas Gavır-Z.Özçelik 7. Örgütsel Davranıs Kongresi Bildiri...}

Dobrin, A. J. (2012). Essentials of management, Ninth Edition, South Western Cengage Learning.

Drisko, J. W. and Maschi, T. (2016). Content analysis, pocket guidesto social work research methods, Oxford University Press.

Erdem, F. (2009). Örgütsel davranış araştırmalarında niş alanlar nasıl belirleniyor? Ulusal yönetim ve organizasyon kongresi yazını üzerine kısa bir değerlendirme, Eskişehir Osmangazi Üniversitesi İIBF Dergisi, 4(1), 65-78.

Herdman, E. A. (2012). Leadership and management: all theory no practice?, Çeviren: Özlem Yazıcı Korkmaz, Hemşirelikte Eğitim ve Araştırma Dergisi, 9(1), 3-9.

Hotamışl1, M. ve Efe, D. (2015). Duygusal zekâ ve liderlik ilişkisi bağlamındaki çalışmaların bibliyometrik analiz ile incelenmesi, Çukurova Üniversitesi IIBBF Dergisi, 19(1), 101-121.

Kaplan, B. ve Kaplan, B. T. (2019). Amme İdaresi Dergisinde Örgütsel Davranı̧̧ alanının izini sürmek: yazın ölçme ve değerlendirme çalışması (2008-2018), 7. Örgütsel Davranış Kongresi Bildiriler Kitab1, 01-02 Kasım 2019, Burdur Mehmet Akif Ersoy Üniversitesi, 1229-1241.

Kaya, A. Y., Fışkın R. ve Nas, S. (2013). Safety Science Dergisinde 2006-2010 yılları arasında yayınlanan makalelerin içerik analizi, Dokuz Eylül Üniversitesi Denizcilik Fakültesi Dergisi, 5(1), 121-139.

Kızıldağ, D. ve Özkara, B. (2016). Türkiye'de Örgütsel Davranış Araştırmalarındaki yönelimler: ulusal yönetim ve organizasyon kongresi örneği, Yönetim Bilimleri Dergisi, 14(28), 609-629.

Koçak, A. ve Arun, Ö. (2006). İçerik Analizi Çalışmalarında Örneklem Sorunu, Selçuk İletişim, 4(3), 21-28.

Krippendorff, K. (2004). Content analysis an introduction to its methodology, Second Edition, Sage Publications.

Maxwell, J. C. (2012) A leader's first responsibility is to define reality, Thomas Nelsun Pub.

Miner, J. B. (2002). Organizational Behaviour, Oxford University Press. 
Mücevher, M. H. (2019). Başarıl yöneticilerin hayat hikâyeleri ve yöneticilik gelişimlerine yansımaları: nitel bir araştırma, [Doktora Tezi], Süleyman Demirel Üniversitesi.

Özkan, M. (2016). Liderlik hangi sıfatları, nasıl alıyor? Liderlik konulu makalelerin incelenmesi, Gaziantep University Journal of Social Sciences, 15(2), 615-639.

Rost, J. C. (1993). Leadership for the twenty-first century, Praeger Publishing.

Sarığlu, S. U. (2014). Yöneticilik ve liderlik ayrımında kişisel farklılıkların rolü, Organizasyon ve Yönetim Bilimleri Dergisi, 6(1), 122-136.

Schermerhorn, J. R., Osborn, R. N., UhlB, M. And Hunt, J. (2012). Organizational Behaviour, John Wileyadn Sons Inc.

Sert, G., Kurtoğlu M., Akıncı A. Ve Seferoğlu, S. (2012). Öğretmenlerin teknoloji kullanma durumlarını inceleyen araştırmalara bir bakış: bir içerik analizi çalışması, akademik bilişsim'12, XIV. Akademik Bilişim Konferansı Bildirileri, Uşak Üniversitesi, 1-3 Şubat, Uşak, 351-357.

Stanfield, A. W. (2009). Defining effective leadership: lead in what ever you do, Tate Publishing.

Torrington, D. and Hall, L. (1987). Personnel management, Prentice Hail International.

Turgut, E. ve Beğenirbaş, M. (2016). Türkiye'deki Örgütsel Davranış yazınına bakış: örgütsel davranış kongrelerinin yazar ve içerik yönünden ağ analizi ile incelenmesi, Gazi Üniversitesi Íktisadi ve İdari Bilimler Fakültesi Dergisi, 18(1), 328-354.

Vijichristiana, M. B. (2017). Organizational Behaviour, Educreaton Publishing.

Yekeler, K. (2015). Dönüştürücü liderlik davranışlarının örgütsel bağllilığa etkisinde etkileşimci liderlik davranışlarının rolü, [Doktora Tezi], Atatürk Üniversitesi Sosyal Bilimler Enstitüsü İşletme Anabilim Dal1, Erzurum.

Zenger, M. M. (2016) Örgütsel bağllliğı etkileyen faktör olarak liderlik ve bir uygulama, [Doktora Tezi], İstanbul Üniversitesi. 